'This is the peer reviewed version of the following article:

Drennan V, Goodman C, Norton C, Wells A. Incontinence in women prisoners: an exploration of the issues. J Adv Nurs. 2010 Sep;66(9):1953-67. doi: 10.1111/j.13652648.2010.05377.x. Epub 2010 Jul 2.

, which has been published in final form at .

http://onlinelibrary.wiley.com/doi/10.1111/j.1365-2648.2010.05377.x/abstract

This article may be used for non-commercial purposes in accordance With Wiley Terms and Conditions for self-archiving'.

\title{
Incontinence in women prisoners: an exploration of the issues
}

\section{ABSTRACT:}

\section{Background}

Nurses and General Practitioners provide primary care services inside UK prisons. While high levels of mental health and addiction problems in women prisoners are recognised there has been less focus on physical problems. Incontinence symptoms are perceived as shameful and stigmatising and frequently help is not sought from health professionals. Guidance for assessing prisoner health does not refer to bladder and bowel symptoms.

\section{Objective}

To explore the extent and management of bladder and bowel problems in women prisoners.

\section{Methods}

Women prisoners in a large, closed prison were surveyed using an anonymous self completed questionnaire. Women resident in the detoxification unit and the hospital unit, absent from their unit at the time of questionnaire distribution or deemed vulnerable by the prison health staff were excluded.

\section{Results}


Questionnaires were offered to 283 women and 246 women agreed to take it. Of those taken, $148(60 \%)$ were returned. Twenty four percent indicated that they disclosed information about bladder and bowel problems in the survey not previously disclosed to anyone else. Forty three per cent of women reported urinary symptoms. Five per cent reported nocturnal enuresis. The majority of women with symptoms reported using sanitary pads and toilet paper for containment of leakage.

\section{Conclusion:}

The study demonstrates that bladder and bowel problems are at least as common in women prisoners as in the general population and nocturnal enuresis and constipation may be more common. The prevalence of these problems in women in prison has not been documented before.

Keywords: women; prisoners; incontinence; prison nursing; constipation

\section{What is already known about this topic?}

- International estimates suggest that between $20-30 \%$ of women aged $18-34$ years and up to $60 \%$ of pregnant women experience urinary incontinence.

- There are no published estimates on the prevalence of bowel and bladder symptoms in the half a million women prisoners internationally.

- Bladder and bowel symptoms are stigmatising and difficult to disclose.

\section{What this paper adds}

- The women prisoners reported a prevalence of bladder and bowel symptoms were equal to and in some instances higher than that reported in community populations of women of similar age.

- Women prisoners have a higher rate of nocturnal enuresis and constipation than that reported by women in community populations. 
- A quarter of those reporting bladder and bowel symptoms had not disclosed then to anyone before.

\section{Implications for practice and/or policy}

- Prison nurses and nurse practitioners involved in reception into prison assessments should ask direct but sensitive questions about bladder and bowel symptoms of women.

- Prison nurses and nurse practitioners in women's prisons should have access to education and training related to the full range of physical as well as mental health problems that commonly present in women prisoners.

- Authorities responsible for women prisoners' access to health care services should ensure they provide or commission access to specialist continence services and products. 


\section{Incontinence in women prisoners: an exploration of the issues}

\section{INTRODUCTION}

The provision of health care in UK prisons is based on a primary care model provided by prison nurse practitioners, prison nurses, and general practitioners (Department of Health 2004). While the high rates of addiction and mental health problems in women prisoners have long been known, only recently has the extent of physical health problems been recognised (HM Chief Inspector of Prisons, 1997). One example is of incontinence: an expert advisory group expressed the opinion that prisoners had significant incontinence problems, with little access to appropriate health care (Department of Health 2000a). Incontinence is perceived as shameful and stigmatising ;it impacts negatively on quality of life and effective therapy can improve emotional well being and self esteem (Donovan et al 2003). However, adults are reluctant to seek to seek help for these problems in the community (Wennberg et al 2009, Hunskaar et al 2004, Norton et al 1988), let alone in an institutional setting where the presentation of one's self as without a stigmatising difference may have additional importance (Goffman 1963). This study aimed to investigate the extent and management of bladder and bowel problems in order to inform prison nursing services and health care services in women's prisons.

\section{BACKGROUND}

\section{The Health Problems of Women Prisoners}

There are over half a million women held in penal institutions world wide (Walmsley 2006). Women are the minority of prisoners in all countries, accounting for between $2-9 \%$ of total prison populations (UN 2008). Most are imprisoned for short periods for non-violent offences, many of which are connected in one way or another with illicit drugs (International Centre for Prison Studies [ICPS] 2008). Women in prison are in the main characterised as poor, from marginalised sections of their societies, with high levels of illiteracy and between $50-80 \%$ have children aged less than 18 years (Taylor 2004, Greenfeld and Snell, 1999). Studies from the 
USA, Brazil and the UK report that between 4 and $12 \%$ of women prisoners are pregnant (Greenfeld and Snell, 1999; Miranda et al, 2000, Caddle and Crisp, 1997) .The health problems of women prisoners reflect their socio-economic status, their occupational risks, as well as their level of access to health care prior to entering prison (United Nations 2008). An international review reported that women prisoners have high rates of drug and alcohol addictions as well mental health illnesses (Fazel, \& Danesh 2002). The interplay of health problems prior to entering prison with the experience of the multiple losses through incarceration (Genders and Player 1987) result in a population with very high levels of mental health problems (O'Brien 2001). Provision of health care for prisoners reflects each country's health system (UN 2008) and many have been criticised for failing to address the health needs of the women in prison (Ross and Lawrence 1998, Quaker Council of Europe 2007). There has been less attention paid to the prevalence of physical health problems women prisoners but studies suggest high rates of infectious diseases, respiratory, musculoskeletal, and menstrual problems (Maruschak \& Beck 1997, Baillargeon et al 2000, Plugge et al 2007).

\section{Bladder and Bowel Problems in Women Prisoners}

Our review of published and unpublished English language papers on the health problems of women prisoners found no data as to the prevalence or management of bladder and bowel problems. This absence is surprising when considered against the prevalence levels of bladder and bowel problems in the wider female population. Urinary incontinence $(\mathrm{UI})$ is the "complaint of any involuntary leakage of urine" (Abrams et al, 2003, p 38). There are three main types of UI in women:

- Stress urinary incontinence, "the complaint of involuntary leakage on effort or exertion, or on sneezing or coughing" (Abrams et al, 2003, p.38)

- Urge urinary incontinence, "the complaint of involuntary leakage accompanied by or immediately preceded by urgency" (Abrams et al, 2003, p.38)

- Mixed urinary incontinence, "the complaint of leakage associated with urgency and also with exertion, effort, sneezing or coughing" (Abrams et al, 2003 p.38).

A meta-analysis of research identified: age, childbirth, obesity, urinary symptoms and functional impairment as the best established risk factors for urinary incontinence in women 
(Hunskaar et al 2005). International evidence suggests that $20-30 \%$ of women aged18-34 years and up to $60 \%$ of pregnant women experience urinary incontinence (Hunskaar et al 2005). The prevalence of all types of $U I$ in women aged 15-44 in the UK is between 1 in 14 and 1 in 20 (Department of Health 2000a). A UK postal survey of 5,544 women over the age of 40 found that $39 \%$ reported clinically significant symptoms such as incontinence, urgency, frequency and nocturia (Perry et al. 2000).

Bowel problems included both incontinence and constipation. Faecal incontinence (FI) has been defined as "the involuntary loss of liquid or solid stool that is a social or hygienic problem" (Norton et al, 2005, p.1523). Faecal incontinence accompanied by incontinence of flatus is known as anal incontinence (Al). Information about $\mathrm{FI}$ and $\mathrm{Al}$ is limited but estimates suggest that the prevalence in adults is between 2-5\% (Kenefick, 2004; Perry et al, 2002). However $13 \%$ of women following childbirth complain of new bowel problems such as faecal urgency and $\mathrm{Al}$ (Sultan et al, 1993). The most common risk factors for $\mathrm{Fl}$ and $\mathrm{Al}$ is age, urinary incontinence, pelvic organ prolapse, diarrhoea, vaginal delivery with sphincter damage, multiparity, mobility impairment, dementia and other neurological conditions (Norton et al, 2005). International studies report between 14\% (younger adult women) and 37\% (post menopause) of women self-report that they are constipated (Chiarelli, et al, 2000; Garrigues et al, 2004). Factors such as sexual abuse have also been associated with urinary and faecal incontinence (Berkelmans et al, 1996). Surveys indicate that $30-50 \%$ of women prisoners have been victims of physical and sexual violence (Greenfield and Snell, 1998, Gorsuch, 1998; Prison Reform Trust 2004).

The absence of prevalence data on bladder and bowel problems in women prisoners may reflect feelings of shame and embarrassment which deter many women from seeking help in the community (Wennberg et al 2009, Hagglund 2007, Hunskaar et al 2004, Norton et al 1988). Prison creates an environment that works against cultural mores of elimination because of the level of surveillance and close proximity with others. Elimination behaviours in all cultures involve some degree of privacy or separation, reflecting Mary Douglas's observations that across cultures faeces and defaecation are linked with danger, defilement, taboo, and pollution (Douglas 1966). Control of bladder and bowels is achieved in early childhood. Adults 
who have symptoms of incontinence have described feelings of shame, humiliation and desire to hide the condition from others (Hagglund 2007, Donovan et al 2003). Women experience incontinence as shameful and stigmatising and how they manage their public persona, preventing any sign of their problems becoming noticeable (Collings \& Norton 2004). The involuntary leakage of polluting excreta is an attribute that is felt as 'defiling' and deeply discrediting i.e. stigmatising (Goffman 1963 p13). Demonstration of an identity that cannot be stigmatised can be important in an institution where not only staff but other inmates may exercise power through acts of violence or bullying (Ireland 2002). In women's prisons bullying is reported to be verbal or take the form of ostracising individuals (HM Prison Service Women's Estate Policy Unit 2003). Incontinence has been found to have a negative impact on women's mental health, their perceptions of self esteem, and their quality of life (Stewart et al, 2003, Kocak et al, 2005). Urinary and faecal incontinence are symptoms of disorders, many of which can be treated following thorough assessment and diagnosis (Abrams et al 2005) although surveys of people with symptoms such as urgency have highlighted those environmental factors can be as important as medical treatment e.g. the availability of public toilets (Norton 2004). Women prisoners are one group who may have bladder and bowel symptoms, may feel they need to manage information about any stigmatising attributes more closely than most and yet may have to do so in more constrained and confined circumstances than other women.

\section{The Prison Health and Nursing Services in England}

England and Wales has just under four and half thousand women prisoners held in 14 prisons, staffed by male and female officers (National Offender Management Services [NOMS] 2008a). Twenty per cent are awaiting trial and over $60 \%$ have sentences of less than six months (Ministry of Justice 2007). Twenty five percent of women prisoners are aged over 40 and 22\% are foreign nationals (Ministry of Justice 2009). Over $70 \%$ of women prisoners have no educational qualifications with over $40 \%$ having reading and writing skills lower than that expected of 11 year old children (HM Inspectorate of Prisons and Probation, 2001). The prison health service has undergone a series of reforms and is provided by the local National Health Service (NHS) Primary Care Trusts (Department of Health 2004). Nurses and general practitioners (GPs) provide the core primary health care service in prisons (Department of Health 2000b, HM Prison Service 2004). Other services such as mental health services and 
midwifery are provided in prisons as commissioned locally. Access to other specialist care outside the prison is via nurse practitioner or general practitioner referral. Before their first night in custody, all prisoners have to have an assessment of immediate physical and mental health needs, significant drug or alcohol abuse and the risk of suicide or self-harm undertaken by a GP with a more general health assessment, usually undertaken by nurses or nurse practitioners offered in the week following reception to the prison (HM Prison Service 2004). Most assessments follow that suggested by the Department of Health which does not specifically make reference to bladder or bowel symptoms (Department of Health 2003).

Prisoners in all English prisons have had 24-hour access to toilets in their cells since 1996 and the prison policy states that all prisoners should be able to use the toilet in privacy i.e. have the whole body screened from all points in the cell or room ( HM Prison Service 2001).

\section{THE STUDY}

Aims

This study aimed to explore the extent and management of bladder and bowel problems in order to inform the provision and practice of prison nursing services and health care services in women's prisons.

\section{Design}

The study used a survey method by prisoner self -complete questionnaire in order to reduce potential embarrassment and consequent non-disclosure of symptoms. This methodology has been successfully used in Scottish prisons in gaining prisoners views about their conditions (Scottish Prison Service 2005).

\section{Participants}

This study took place in a closed women's prison with a bed capacity at the time for 500 prisoners held 11 units in 4-5 bedded dormitories and single cells. Actual numbers of prisoners resident fluctuated as women were daily remanded (i.e. admitted), transferred and released. Each cell or dormitory had an integral toilet. The detoxification and hospital units (with 70 beds) of the prison were excluded from the study as the women were considered too unwell to participate. Women identified as mentally vulnerable by the prison staff at the time the survey 
was distributed were also excluded. Women absent from their residential units at the time of the questionnaire distribution were also excluded.

\section{The Self Report Questionnaire}

The self-report questionnaire had to be accessible to people with a reading age below 11 years and from a variety of cultural backgrounds. Currently available validated questionnaires (Shaw et al, 2002; Jackson et al, 1996) did not meet both these criteria. A self-report questionnaire that met these criteria was developed from those currently available. Face and content validity was established through review by specialist continence advisors. Acceptability and accessibility was determined through the development process with prison health staff, women prisoners and the prison governor. The colloquial and relatively polite terms 'peeing' and 'pooing' were used instead of urinating and defaecating. Thirty one women prisoners piloted the questionnaire and further amendments were made. The final questionnaire (Box 1) offered a range of answers to circle and a space for additional comments. Information was provided to indicate which symptoms, for example blood in urine, required consultation with a GP or nurse.

\section{Box 1 about here}

\section{Data Collection}

The researchers aimed to gain the trust of the prisoners so that they would be willing participate and to disclose sensitive information (Bosworth, 2005; Liebling, 1999). Women were approached in their cells by a researcher and offered the questionnaire pack, which complied with security requirements. This included a self sealing return envelope to be handed back later or via one named prison nurse. The invitation to participate and the consent procedure ensured that the prisoners knew that they could refuse to take part without any consequences. The questionnaire was offered only once to avoid any perception of coercion to complete. The questionnaire required no items of personal identification on it. The prison authorities authorised the questionnaire distribution and collection to the different residential units over 4 weekends to lessen the demand on prison staff time to accompany the researcher. 


\section{Ethical Issues}

Permissions to conduct the study were gained from the prison governor, the prison service, the senior prison general practitioner, and the prison health service. Ethical review was undertaken by a NHS Local Research Ethics Committee designated for considering prison studies. In addition it was reviewed by the prison service in accordance with HM Prison Service standing orders. Particular ethical issues the study had to address included: ensuring the prisoners felt there was no coercion to participate and they were free to choose, without penalty or effect on their prison tariff.

\section{Data Analysis}

Quantitative data were entered onto a statistical package (SPSS version 12) database and analysed using descriptive statistics and the Chi-squared $\left(X^{2}\right)$ test, with a significant finding indicated by a $p$-value of $p<0.05$. Replies to the open ended questions and other comments made by the respondents were transcribed and thematically analysed (Robson 2002) by two researchers independently and then compared, resolving any differences in discussion with the wider research team.

\section{RESULTS}

Two-hundred-and-eighty-three women were approached and 246 agreed to take the questionnaire. One hundred and forty eight (60\%) returned the questionnaire. Free text comments were made on 46 questionnaires. Thirty five women (24\%) reported they had shared information on bladder and bowel problems in their responses that they had not previously told to anyone else. Eleven women (7\%) indicated they were too embarrassed to complete the questionnaire; while a further three wrote derogatory comments, indicating that they disapproved of the subject matter. There were between one and twelve missing answers in all questionnaires returned.

\section{Profile of Respondents}


Eighty percent of the women were under 40 years, nine per cent were pregnant, and $22 \%$ had 3 or more children (Table 1). Twenty four percent had a language other than English as their first and $37 \%$ had education beyond 16 years (the UK earliest school leaving age at the time of the study). Nearly half the respondents reported mental health and/or physical health problems and taking daily prescribed medication (see Table 2). Of those who took daily prescribed medication, anxiolytic/hypnotic drugs, antidepressants and methadone for drug rehabilitation were the most commonly reported types followed by anti-inflammatory/painkilling drugs and medication for hypertension and asthma

Table 1 about here

Table 2 about here

\section{Reported Symptoms and Management of Bladder and Bowel Problems}

Sixty women (43\%) reported symptoms of urinary incontinence of all types. Forty four women (31\%) reported symptoms of stress incontinence, 36 (24\%) reported symptoms of urge incontinence and $20(14 \%)$ reported symptoms of both stress and urge incontinence (Table 3 ).

\section{Table 3 about here}

Significantly more women aged 41 and over than those aged under 40 reported stress incontinence ( $X^{2}$ test; $2 \mathrm{df} ; \mathrm{p}=0.03$ ) and urge incontinence $\left(X^{2}\right.$ test $2 \mathrm{df} ; \mathrm{p}=0.028$ ). Significantly more women who had had three or more children reported stress incontinence than those who had no children ( $X^{2}$ test; $1 \mathrm{df} ; \mathrm{p}=0.032$ ). Significantly more women who reported a tear or an episiotomy at childbirth reported stress and urge incontinence than those who had not $\left(X^{2}\right.$ test; 1df; $p=0.002)$.

Seventy five women (51\%) reported nocturia and eight women $(5 \%)$ reported nocturnal enuresis (bed-wetting). Seventeen women (12\%) reported pain when passing urine (NB this was one of the questions that a positive response indicated to the respondent that they should seek medical advice). 
A significantly higher proportion of those who reported they were currently receiving medical treatment for ill health and of those who reported taking daily-prescribed medication reported pain on passing urine than those who were not being treated ( $x^{2}$ test; $1 \mathrm{df} ; \mathrm{p}=0.001$ ) or taking daily medications ( $x^{2}$ test; $1 \mathrm{df} ; \mathrm{p}=0.033$ ). Also a significantly more of those who reported taking medication reported symptoms of stress incontinence $(41 \%)$ than those on no medications $(22 \%)\left(x^{2}\right.$ test; $\left.1 \mathrm{df} ; \mathrm{p}=0.016\right)$.

Twenty-five percent $(n=37)$ of women who had reported some form of bladder problem reported that they had bladder problems before they came into prison. $43 \%(n=63)$ said the problem started after imprisonment.

Of those that completed the question about methods of urine containment they reported: 22 used panty liners to protect their clothing, 13 used nothing, 9 used toilet paper, 9 used sanitary towels and 3 used continence pads.

Sixty per cent $(n=88)$ of the respondents indicated that constipation was a regular problem (table 4$)$ and $16 \%$ percent $(n=23)$ reported taking laxatives at least once a week. Respondents reported other bowel problems, some likely to be associated with the problems of constipation. Thirty percent $(n=42)$ indicated incontinence of flatus. Eight percent $(n=11)$ of the women reported that they soiled themselves. There were significant associations between women aged 41 and over and those who had given birth to three or more children with a reported lack of control of flatus ( $x^{2}$ test; $2 \mathrm{df} ; \mathrm{p}=0.023$ ) and ( $x^{2}$ test; $\left.1 \mathrm{df} ; \mathrm{p}=0.005\right)$. There was also a 'borderline' significant association between those who complained of ill health and lack of control of flatus ( $x^{2}$ test; $1 \mathrm{df} ; p=0.050$ ) than those who had no health problems. Five percent $(n=7)$ reported having blood in their faeces regularly and $26 \%(n=38)$ reported blood in their faeces sometimes. The wording of the question made it impossible to determine whether this was blood in the faeces or if it was faeces smeared with blood from rectal outlet bleeding.

\section{Women Prisoners' Views.}


Forty six women wrote additional comments on the questionnaire. Many of these were made to illuminate or interpret their answer to the previous question for example this women who reported frequency symptoms suggested that her bladder problems were a physiological response to their imprisonment and should not be medicalised:

"Frequent passing urine for me could be due to nerves/excitement, therefore is not a problem". (Respondent 131)

Twenty three women wrote comments after the questions related to bowel symptoms. The prison diet and lack of availability of fresh fruit and vegetables was repeatedly identified as the source of bowel problems:

'I think if you give us better food it will make us go to the toilet as normal as you should, and a lot of fruits. I think if we eat yam and banana it will improve.' (Respondent 60)

Twenty five women responded to the open ended question at the end of the questionnaire inviting additional comments on bladder and bowel problems, suggested solutions on dealing with these problems in a prison environment. These comments related to themes of wider health issues, assistance from the prison nurses, environmental concerns and finally problems with medical confidentiality. Each of these is illustrated in turn.

A few women took the opportunity to make wider comments on their health problems as in this example:

'im not getting my antydeppressant and I need them I feel very low and depprest.' [I'm not getting my anti-depressants and I need them. I feel very low and depressed.] (Respondent 10)

Fifteen described in more detail their bladder and bowel problems as this example shows:

"A problem is leaking feaces [faeces] and getting sore from constant wiping" (respondent 89)

Some respondents reported that the prison nurses had addressed their bladder and bowel problems which had been present before they were imprisoned as in this illustration: 
I must have had an infection when I came in to prison - because I used to wee all the time - little \& often - but I saw a nurse - attended special clinic - \& it's got a lot better - I took antibiotics. Outside l'm a crack user - \& don't get around to dealing with certain issues.' (Respondent 55)

Environmental concerns and the risks of toilets as a source of contamination were commented on by a number of women:

'A lot of women don't like going to the toilet because of fear of contracting infections and diseases.' (Respondent 21).

The challenge for prisoners is that supplies of toilet paper and any menstrual containment products are in the control of the staff:

'There has been a large problem with having availability of toilet paper. Often the wings [units within the prison] run out before the next order comes in' (Respondent 101)

Issues of privacy and control of access to toilets were noted by a number of women: an issue that becomes more significant for women who have bowel problems or urge urinary incontinence:

"Sometimes when you're on freeflow (ie doctors, optitions[opticians]) the officers won't take you to the toilet because they say you should have gone in your room beforehand.' (Respondent 90)

"Who are we; only prisoners, we have no say about a little private poo. Officer can open your hatch whenever they choose" (Respondent 18)

Some women commented on the difficulties in accessing help for some of the bladder and bowel problems as illustrated in this comment:

"Very few women in prison are aware of the help available, e.g. laxatives, bed covers etc. and getting these facilities from staff is very difficult anyway. (Respondent 125)

Comments were also written indicating that seeking help for intimate problems could result in 
their revelation to other prisoners and other prison staff as exemplified in the following comment:

'Staff openly discuss such medical issues if you do report them, which means other inmates can become aware of any difficulties" (Respondent 23)

\section{DISCUSSION}

\section{Limitations}

This study of a small self -completed survey in the UK and as such it has limitations. While the respondent numbers were small it had a response rate equal to that found in community studies on the same topics (Vandoninck et al 2004) and UK self complete questionnaires of prisoners views (Scottish Prison Service 2005). It was acceptable to some but not all women prisoners. The methodology did not allow us to determine if there were particular subpopulations who found it least acceptable. The $40 \%$ non-response rate also indicated that the women were able to exercise choice, an important issue in undertaking research in a prison environment. That so many women chose to compete the questionnaire with no immediate benefit to them, suggests that many considered these issues important to women prisoners.

The demographic profile of the respondents reflected the profile of UK women prisoners except for their education levels; $25 \%$ of respondents had remained in education after the age of 16 compared to $11 \%$ in the general women prisoner population (Ministry of Justice 2007). The use of the written medium was inevitably more acceptable to those with longer educational histories but it did not deter some women with little formal education completing the survey.

The use of an adapted data collection tool was not ideal but the positive statistical association found in the respondent prevalence rates for urinary symptoms with the known risk factors e.g. age over forty and more than three births (Hunskaar et al 2005) offers some validation for the adaptations and confidence in the findings. 


\section{Reported Bladder and Bowel Symptoms}

Reported symptoms of urinary incontinence were higher in this predominately under 40 year old population than in that of the general population (Hunskaar et al 2005). Seventeen women $(12 \%)$ reported pain when passing urine, which is more than 20 times the proportion of the general female population (Hunskaar et al 2005). Seventy five women (51\%) reported nocturia which is much higher than in population surveys of these ages but may be caused by or contributed to by sleep problems known to be prevalent in prisoners (Singleton et al 1998).

The reported methods of containing leaking urine and faeces indicated that the majority of women were unlikely to have discussed these symptoms with the nurses or GPs. Most used panty liners $(n=22)$, followed by toilet paper $(n=9)$ and sanitary towels $(n=9)$ to contain leakage. Three women reported using incontinence pads, available only through the prison health service. 9 women reported leakage problems but used no form of containment. For women in prison the management of leakage problems without seeking help may be important in maintaining their presentation of self as whole. The challenge for women prisoners in the UK as in prisons in other countries (Maeve 1999) is that supplies of toilet paper and any menstrual containment products are in the control of the staff, often male. While the prison standards specify that menstrual containment products must be available there are no references to issues of management or containment for bowel and bladder problems (NOMS 2008b). Those who might approach the health care staff may be daunted by the perceived problems in maintaining confidentiality. Prisoners in this study reported problems in confidentiality and acess to care: these problems have been reported in previous UK studies (Plugge et al 2008, Condon et al 2007), and in other countries (Stoller 2003).

Eight women (5\%) reported nocturnal enuresis (bed-wetting). The only community population survey of adult women reporting any nocturnal enuresis reported a prevalence of $0.5 \%$ (Hirasing et al, 1997). Nocturnal enuresis is a heteregeneous disorder more common in children. Causal factors and associations include stressful life events, constipation, genetic predisposition, and diuretic drinks (Hjalmas et al 2004). Women in prison by definition are under stress and are characterised by high levels of stressful events in their lives and mental 
health problems (O' Brien 2001). One prison office commented at a presentation of the findings in the prison: 'I always think that night time is really hard for the women-it's when all the demons come out.' While there was no other risk factor was found to be statistically significant with those reporting nocturnal enuresis, constipation was reported by many women. The problem of soiled bed sheets and mattresses is recognised in the Prison Service which has service standards which indicate that officers should ensure women prisoners have clean bed sheets and very soiled mattresses should be replaced ( NOMS 2008b).

Sixty per cent $(n=88)$ of the respondents indicated that constipation was a regular problem and $16 \%$ percent $(n=23)$ reported taking laxatives at least once a week. Population surveys suggest about $15 \%$ of adults experience constipation (American College of Gastroenterology (2005), while up to $40 \%$ of pregnant women experience problems with constipation (Cullen and O'Donoghue 2007).

While the English prison service has catering guidelines (HM Prison Service 1999) on a diet for good health and avoiding constipation, it may be that other factors such as lack of exercise, low fluid intake and side effects of medication contribute to the scale of the problems. The respondents attributed this to diet and privacy issues. Most of these factors could be addressed in the prison situation.

Women prisoners also reported environmental issues that impact on bladder and bowel symptoms. The fear of contamination from excreta in shared western style toilets has been noted before and results in women 'hovering' above toilet sets (Greed 2003). Official reports in the UK repeatedly comment on the lack of cleanliness in some prison sanitary facilities (HM Inspectorate of Prisons 2008). The lack of privacy in using toilets and potential effects for women have also been reported elsewhere (Thomas 1996, UN 2008).

The study demonstrates that bladder and bowel problems are as common in women prisoners as in the general population in and bedwetting in particular may be more common. To the best of our knowledge, the prevalence of these problems in women in prison has not been documented before. We suggest that health assessments undertaken by nurses should ask directly about bladder and bowel problems. It may be that prison nurses require additional 
support through education and training in how to raise these questions sensitively with women prisoners' as well greater knowledge about the treatment and management of bladder and bowel symptom. Creating the opportunity for women to disclose can lead to treatment but perhaps as importantly in the prison setting, access to appropriate containment pads, pants and night-time protection while women are in custody. In the UK finance for this type of support is within the NHS as are specialist continence assessment and management services. The challenge for prison health services is to ensure that this specialist help and containment products are available for a female prison population and that continuity of follow-up occurs on release. In England this means that commissioning Primary Care Trusts need to consider these aspects and access to specialist services.

In Europe, under the auspices of the Regional Office of the World Health Organisation, there are developments to support health promoting prisons and improve health care in prisons (WHO Regional Office for Europe 2007, Palmer 2007). The recent draft Kyiv Declaration on Women's Health in Prisons (WHO Regional Office for Europe 2008) advocates that there should be more attention paid to the needs of women in prison for example around menstrual problems but does not raise the issue of incontinence as described here. At a policy influencing level there is an opportunity to consider women prisoners health needs more broadly including those that can be most shameful and stigmatising such as adult bedwetting and urinary incontinence.

\section{CONCLUSION}

The study demonstrates that bladder and bowel problems are at least as common in women prisoners as in the general population and nocturnal enuresis and constipation may be more common. The prevalence of these problems in women in prison has not been documented before. Despite questions being raised as to the appropriateness of custodial sentences for women (Home Office 2007), current trends in England as in many other countries indicate the numbers of women prisoners are rising (Walmsley 2006). This study suggests that both prison nurses and also prison services need to take cognisance of the scale of the problems and develop systems that appropriately address the health needs of women in custody in a non- 
stigmatising manner. 


\section{REFERENCES}

Abrams, P., Cardozo, L., Fall, M., Griffiths, D., Rosier, P., Ulmsten, U., van Kerrebroeck, P., Victor, A., \& Wein, A. (2003), The standardisation of terminology in lower urinary tract function: report from the standardisation sub-committee of the International Continence Society. Urology, vol. 61, pp. 37-49.

Abrams P, Andersson KE, Brubaker L, Cardozo L, Cottenden A, Denis L et al (2005). The recommendations of the international scientific committee: evaluation and treatment of urinary incontinence, pelvic organ prolapsed and faecal incontinence. pp 1589-1630 in $3^{\text {rd }}$ International Consultation on Incontinence Volume 2 Incontinence; Management (2005) pp. 255-312. Abrams P, Cardozo L, Khoury S and Wein A eds. Accessed last at www.icsoffice.org/publications on 10th January 2009

American College of Gastroenterology Chronic Constipation Task Force (2005). An evidence-based approach to the management of chronic constipation in North America. American Journal of Gastroenterology 100(Suppl 1), S1-S4.

Baillargeon J, Black SA, Pulvino J, Dunn K. (2000) The disease Profile of Texas Prison Inmates Ann Epidemiol. 2000 Feb;10(2):74-80

Berkelmans, I., Leroi, A.-M., Weber, J., \& Denis, P. (1996), Faecal incontinence with transitory absence of anal contraction in sexually or physically abused women, European Journal of Gastroenterology \& Hepatology, vol. 8, no. 3, pp. 235-238.

Bosworth, M., Campbell, D., Demby, B., Ferranti, S. M., \& Santos, M. (2005). Doing prison research: Views from inside. Qualitative Inquiry, vol. 11, no. 2, pp. 249-264.

Caddle D and Crisp D (1997) Imprisoned Women and Mothers Great Britain Home Office Research Development and Statistics Directorate Information and Publications Group

Chiarelli, P., Brown, W., \& McElduff, P. (2000). Constipation in Australian women: prevalence and associated factors", International Urogynecology Journal and Pelvic Floor Dysfunction, vol. 11, no. 2, pp. 71-78.

Collings S \& Norton C (2004) Women's experiences of faecal incontinence. British Journal of Community Nursing, 9, 12,, pp 520 - 523

Condon L, Hek G, Harris F, Powell J, Kemple T, Price S. (2007). "Users' views of prison health services: a qualitative study." Journal of Advanced Nursing 58(3): 216-226.

Cullen, G. and O'Donoghue, D. (2007) Constipation and pregnancy. Best Practice \& Research Clinical Gastroenterology 21(5), 807-818.

Department of Health (2000a). Good practice in continence services, London: Department of Health.

Department of Health (2000b). Nursing in Prisons; Report by the Working Group considering the development of prison nursing, with particular reference to health care officers. HM Prison Service, NHS Executive, The National Assembly for Wales. London : Department of Health Accessed last on $8 / 10 / 08$ at http://www.dh.gov.uk/en/Publicationsandstatistics/Publications/PublicationsPolicyAndGuidance/DH_40 06736 
Department of Health (2003) Good Medical Practice for Doctors providing Primary Care Services in Prison. London: Department of Health

Department of Health (2004). Work Programme for Prison Health. London: Department of Health.

Donovan J, Badia X, Corcos M et al. (2003) Symptom and quality of life assessment. In Abrams P, Cardozo L, Khoury S, Wein A (eds). Incontinence: Proceedings of the 2nd International Consultation on Incontinence. p269-316.Plymouth: Health Publications Ltd;:

Douglas M (1966) Purity and Danger an analysis of concepts of pollution and taboo. London: Routledge and Keegan

Fazel, S. \& Danesh, J. (2002), Serious mental disorder in 23000 prisoners: a systematic review of 62 surveys, The Lancet, vol. 359, pp. 545-550.

Garrigues, V., Galvez, C., Ortiz, V., Ponce, M., Nos, P., \& Ponce, J.( 2004), Prevalence of constipation: agreement among several criteria and evaluation of the diagnostic accuracy of qualifying symptoms and self-reported definition in a population-based survey in Spain", American Journal of Epidemiology, vol. 159 , no. 5, pp. 520-526.

Genders E and Player E (1987) Women in Prison: The Treatment, the Control and the Experience: in P Carlen and A Worrall Eds. Gender Crime and Justice Milton Keynes: Open University Press

Goffman E. (1963) Stigma. Notes on the Management of Spoiled Identity. Prentice-Hall: Englewood Cliffs, New Jersey.

Gorsuch, N. (1998), "Unmet need among disturbed female offenders", The Journal of Forensic Psychiaty \& Psychology, vol. 9, no. 3, pp. 556-570.

Greed C (2003) Public Toilets. Chapter 5 in Greed C Inclusive Urban Design:: London Architectural Press,

Greenfield LA and Snell TL , (1999) Women Offenders, Bureau of Justice Statistics, U.S. Department of Justice (December 1999, rev. 10/3/00),

Hagglund D and Wadensten B. (2007). Fear of humiliation inhibits women's care seeking behaviour for long-term urinary incontinence. Scand J Caring Sci 21: 305-12

Hirasing, R. A., van Leerdam, F. J. M., Bolk-Bennink, L., \& Janknegt, R. A. (1997). Enuresis nocturna in adults. , Scandinavian Journal of Urology and Nephrology, vol. 31, no. 6, pp. 533-536.

Hjalmas, K., Arnold, T., Bower, W. et al. (2004) Nocturnal enuresis: an international evidence based management strategy. Journal of Urology 171(6 Pt 2), 2545-2561.

HM Chief Inspector of Prisons. (1997). Women in prison: a thematic review by HM Chief Inspector of Prisons. London: Home Office

HM Inspectorate of Prisons (2008) HM Inspectorate of Prisons Report 2007-2008. London: Home Office.

HM Prison Service. (1999). Prison Service Catering Manual, PSO 5000. London :HM Prison Service. 
HM Inspectorates of Prisons and Probation. (2001). Through the Prison Gate; A Joint Thematic Review. London: Home Office.

HM Prison Service. (2001). Certified Prisoner Accommodation, PSO 1900. London Home Office.

HM Prison Service (2004) The Health Services for Prisoners Standards for Audit HM Prison Service . London: Home Office

HM Prison Service : Womens Estate Policy Unit (2003) Working with Women Prisoners. HM Prison Service editor Ash B. $4^{\text {th }}$ edition. London: HM Prison Service.

Home Office (2007) The Corston Report: A report by Baroness Jean Corston of a review of women with particular vulnerabilities in the criminal justice system. Executive Summary. London: Home Office

Hunskaar S, Lose G, Sykes D, Voss S. (2004) The prevalence of urinary incontinence in women in four European countries.BJU Int;93: 324-30

Hunskaar, S., Burgio, K., Clarke, A., Lapitan, M. C., Nelson, R., Sillen, U., \& Thom, D. (2005), "Epidemiology of Urinary (UI) and Faecal (FI) Incontinence and Pelvic Organ Prolapse (POP)," in $3^{\text {rd }}$ International Consultation on Incontinence Volume 1 Incontinence; Basics and Evaluation, (2005) pp. 255-312. Abrams P, Cardozo L, Khoury S and Wein A eds. Accessed at www.icsoffice.org/publications on 10th January 2009

International Centre for Prison Studies [ICPS] (2008) International profile of women's prisons. London: Kings College, University of London. Accessed last 22/01/10 at http://www.kcl.ac.uk/depsta/law/research/icps/downloads

Ireland J ( 2002) Bullying among Prisoners : Evidence, Research and Interventions. London: Routledge Jackson, S., Donovan, J., Brookes, S., Eckford, S., Swithbank, L., \& Abrams, P. (1996). The Bristol Female Lower Urinary Tract Symptoms questionnaire: development and psychometric testing. British Journal of Urology, vol. 77, pp. 805-812.

Kenefick, N. (2004). The epidemiology of faecal incontinence, in Bowel continence nursing, C. Norton \& S. Chelvanayagam, eds., The Alden Press, Oxford, pp. 14-21.

Kocak, I., Okyay, P., Dundar, M., Erol, H., \& Beser, (2005) E. Female Urinary Incontinence in the West of Turkey: Prevalence, Risk Factors and Impact on Quality of Life. European Urology.

Liebling, A. 1999, "Doing research in prison: Breaking the silence?", Theoretical Criminology, vol. 3, no. 2, pp. 147-173.

Maeve, KM (1999) Adjudicated Health: incarcerated women and the social construction of health. Crime, Law and Social Change,31,49-71 
Maruschak, L. M., \& Beck, A. J. (2001). Medical problems of inmates (NCJ 181644). Washington, DC: Department of Justice, Bureau of Justice Statistics.

Ministry of Justice (2007) Offender Management Caseload Statistics 2006 London National Statistics Office.

Ministry of Justice (2009) Statistics on Women and the Criminal Justice System. London: Ministry of Justice.

Miranda AE, Vargas PM, St. Louis ME \& Viana MC (2000). Sexually transmitted diseases among female prisoners in Brazil: prevalence and risk factors. Sexually Transmitted Diseases, 27: 491-495.

National Collaborating Centre for Women's and Children's Health (2006) National Institute of Clinical Excellence CG40 Urinary Incontinence: Full clinical guidance. London Royal College of Obstetricians and Gynaecologists.

National Offender Management Services[NOMS] (2008a) Prison Population and Accommodation Briefing Bulleting 05/12/2008 . London: HM Prison Service

National Offender Management Service [NOMS], (2008b) The Offender Management Guide to Working with Women Offenders. Ministry of Justice May 2008

Norton C (2004) Nurses, Bowel Continence, Stigma and Taboos Journal of Wound, Ostomy and Continence Nursing: Volume 31(2)March/April 2004p 85-94

Norton, C., Whitehead, W. E., Bliss, D. Z., Metsola, P., \& Tries, J. (2005) Conservative and Pharmacological Management of Faecal Incontinence in Adults," in Incontinence; Basics and Evaluation, 2005 edn, P. Abrams et al., eds., Health Publication Ltd, Plymouth, pp. 1521-1563.

Norton, P. A. MacDonald, L. D. Sedgwick, P. M. and. Stanton S. L. (1988)

Distress and delay associated with urinary incontinence, frequency, and urgency in women. BMJ. 1988 November 5; 297(6657): 1187-1189.

O'Brien M , Mortimer L, Singleton N and Meltzer H (2001) Psychiatric Disorder among women prisoners in England and Wales Further analysis of data from the 1997 ONS survey of psychiatric morbidity among prisoners in England and Wales. London: Office for National Statistics

Palmer J (2007) Special health requirements for female prisoners p157-170 in Møller L, Stöver H, Jürgens R, Gatherer A and Nikogosian H (eds) (2007) Health in prisons

A WHO guide to the essentials in prison health. Copenhagen: WHO Regional Office for Europe.

Perry, S., Shaw, C., Assassa, P., Dallosso, H., Williams, K., Brittain, K. R., Mensah, F., Smith, N., Clarke, M., Jagger, C., Mayne, C., Castleden, C. M., Jones, J., \& Mcgrother, C. (2000),An epidemiological study to establish the prevalence of urinary symptoms and felt need in the community: the Leicestershire MRC Incontinence Study. Leicestershire MRC Incontinence Study Team. J Public Health Med., vol. 22, no. 3, pp. 427-434.

Perry, S., Shaw, C., Mcgrother, C., Matthews, R. J., Assassa, R. P., Dallosso, H., Williams, K., Brittain, K. R., Azam, U., Clarke, M., Jagger, C., Mayne, C., \& Castleden, C. M. (2002).Prevalence of faecal incontinence in adults aged 40 years or more living in the community. Gut, vol. 50, no. 4, pp. 480-484. 
Plugge E, Douglas N and Fitzpatrick R (2007) The Health of women in prison: Study Findings. Oxford: Department of Public Health University of Oxford at http://www.publichealth.ox.ac.uk/units/prison/200702-13.6702780065

Plugge, E., Douglas N. Fitzpatrick R., et al. (2008). "Patients, prisoners, or people? Women prisoners' experiences of primary care in prison: a qualitative study." Br J Gen Pract 58(554): 630-6.

Prison Reform Trust, (2004) Evidence to the House of Commons Home Affairs Select Committee cited in House of Commons Home Affairs Select Committee First Report Session 2004-2005 Rehabilitation of Prisoners. HC 193-I Section 12 para 290. London: House of Commons.

Quaker Council for European Affairs (2007) Women in Prison A Review of Conditions in Member States of the Council of Europe: Quaker Council for European Affairs

Robson C (2002) Real World Research. Oxford : Blackwell Publishers

Ross, P. H., \& Lawrence, J. E. (1998). Health care for women offenders. Corrections Today, 60(7), 122-129.

Scottish Prison Service (2005) Thematic Report $8^{\text {th }}$ Prisoner Survey 2005 . Edinburgh: The Scottish Prison Service. 2005 accessed last on 2/4/09 at

http://www.sps.gov.uk/Default.aspx?DocumentID=21190703-e7b4-4abc-bc83-44b5d0f06f69

Scottish Prison Service (2008) Prisoner Survey 2008. Research and Management Information.

Shaw, C., Matthews, R. J., Perry, S. I., Assassa, R. P., Williams, K., Mcgrother, C., Dallosso, H., Jagger, C., Mayne, C., \& Clarke, M. (2002).Validity and reliability of an interviewer-administered questionnaire to measure the severity of lower urinary tract symptoms of storage abnormality: the Leicester Urinary Symptom Questionnaire. BJU International, vol. 90, no. 3, pp. 205-215.

Singleton, N., Meltzer, H., Gatward, R., Coid, J., \& Deasy, D. (1998).Psychiatric morbidity among prisoners: Summary report. Office for National Statistics, Department of Health..

Stewart, W. F., Van Rooyen, J. B., Cundiff, G. W., Abrams, P., Herzog, A. R., Corey, R., Hunt, T. L., \& Wein, A. J. (2003). Prevalence and burden of overactive bladder in the United State. , World Journal of Urology, vol. 20, pp. 327-336.

Stoller N (2003) Space, place and movement as aspects of health care in three women's prisons Social Science \& Medicine Volume 56, Issue 11, June 2003, Pages 2263-2275

Sultan, A. H., Kamm, M. A., Hudson, C. N., Thomas, J. M., \& Bartram, C. I. (1993), Anal-sphincter disruption during vaginal delivery. N Engl.J Med., vol. 329, no. 26, pp. 1905-1911

Taylor R (2004) Women in Prison. Geneva :The Quaker United Nations Offices 
Thomas D. Q (1996) All too Familiar Sexual Abuse of Women in U.S. State Prisons Human Rights Watch . Accesed last on 22/1/10 at http://www.hrw.org/en/reports/1996/12/01/all-too-familiar

United Nations Office on Drugs and Crime (2008) United Nations Handbook on Handbook for Prison Managers and Policymakers on Women and Imprisonment. New York: United Nations.

US Justice Department ( 2008) Bureau of Justice Statistics Bulletin. Prison Inmates at Mid-Year 2007.

Vandoninck V, Bemelmans BL, Mazzetta C, Robertson C, Keech M, Boyle P, Kiemeney LA; UREPIK study group. (2004) The prevalence of urinary incontinence in community-dwelling married women: a matter of definition. BJU ITt. 2004 Dec;94(9):1291-5.

Walmsley R (2008) World Prison Population List. $7^{\text {th }}$ edition London: Kings College London International Centre for Prison Studies.

Wennberg AL, Molander U, Fall M, Edlund C, Peeker R, Milsom I. (2009) Lower urinary tract symptoms: lack of change in prevalence and help-seeking behaviour in two population-based surveys of women in 1991 and 2007. BJU international 104; 70. 954-959

Walmsley R (2006) World Female Imprisonment List. London: Kings College London International Centre for Prison Studies.

WHO Regional Office for Europe (2007) Health in prisons A WHO guide to the essentials in prison health. Denmark: WHO Regional Office for Europe

WHO Regional Office for Europe (2008) WHO Conference on Women's health in Prison Correcting gender inequities in prison health: November 2008. Denmark: WHO Regional Office for Europe

WHO and UNICEF (2000), Global Water Supply and Sanitation Assessment, 2000 Report, World Health Organization, UNICEF and Water Supply and Sanitation Collaborative Council,

Wyner R (2003) From the Inside: Dispatches of a Women's Prison. London Aurum Press 


\section{$\underline{\text { BOX } 1}$}

\section{The Survey questions}

NB the original was in larger script, widely spaced and on bright paper.

First a few questions about yourself

1. How old are you?
20 years or $21-30$
$31-40$
$41-50$
over 50

under

2. What is your first language?

\section{English}

If not English please write your first language

3. How old were you when you left full time education?
12 years or less
16 years or less
17 or 18 years
19 years or more

4. Are you on remand?

Yes No

5. Have you been convicted and are serving your prison sentence?

No Yes and the Yes and the Yes, serving over 3
sentence is less than sentence is between years
a year

6. Have you been in the detox unit in prison since your arrest?

Yes No

Now a few questions about your health and medical history

7. Have you had any children?

$\begin{array}{llll}\text { None } & 1 \text { child } & 2 \text { children } & 3 \text { children } 4 \text { or more }\end{array}$

8. If you have given birth, did any of the births involve a caesarean operation?

Yes No

9. If you have given birth, did you have to have stitches down below (in your perineum) afterwards?

Yes No

10. Are you pregnant now?

Yes No

11. Do you have any health problems that are currently treated by a doctor?

Yes No

12. If yes please write them here

13. Do you take any daily-prescribed medication for a health problem?

Yes No

14. If yes please give name of medicine

Now we want to know about any problems that you have with peeing (passing urine)

15. Do you leak some urine (pee) when you cough or laugh or sneeze or exercise?

Yes No Go to question

17

16. If you answered yes to question 15, how often does this problem happen?

Every day Some days every Occasionally but Rarely

17. Do you feel you need to pee very frequently?

Yes No Go to question 19

18. If you answered yes to question 17 , how many times a day do you need to pee?

6-7 times a day 8-10 times a day 11-15 times a day 16 or more times a 
day

19. Do you have difficulty holding on to the pee once you feel the urge to go?

Yes No Go to question 21

20. If you answered yes to question 19, how often does this happen?

Most of the time Sometimes Occasionally

21. Do you ever have an accident and wet yourself because you could not get to the toilet in time?

Yes No Go to question 23

22. If you answered yes to question 21 , how often?

Every day Some days every Occasionally but most months Rarely week

23. If you have problems with urine leakage, do you use anything to soak up the pee that you leak? Circle all that apply. If not, go to question 24.

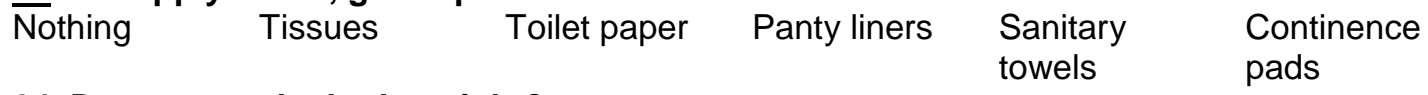

24. Do you wet the bed at night?

Yes No Go to question 26

25. If you do wet the bed, how often does this happen?

Every night Some nights most weeks

Occasionally

26. Do you have to get up during the night to pee?

Yes Sometimes No Go to question 28

27. If you get up at night to pee, how many times do you have to get up?

1 a night 2 times a night 3 or more times a night

28. Does it hurt or burn when you pass urine /pee?

Yes No

If you answer yes to this question you may want to discuss this with the prison nurse, as it may be a sign of an infection.

29. If you have problems with wetting yourself, having to pee often or wetting the bed, did you have these problems BEFORE you came into prison?

Yes No

(Remember you can ask to speak to the prison nurse if you do have problems)

Some questions about opening your bowels (having a poo)

30. How often do you open your bowels (have a poo)?

More than once a day less often in varies

once a day $2-3$ days

31. Do you have problems with constipation or opening your bowels at the moment in prison?

Yes Sometimes No

32. If you answered yes to question 31 , what do you think might improve the problem for you?

33. Do you take laxatives?

Yes Sometimes No Go to question 35

34. If you answered yes or sometimes to question 33 , how often?

every day 2-3 times a week once a week less frequently

35. When you need a poo, do you have to find a toilet quickly?

Yes Sometimes No

36. Do you ever have an accident and soil yourself because you could not get to the toilet in time?

Yes No (Go to question 38)

37. If you answered yes to question 36 , how often?

Every day Some days every Occasionally but Rarely

38. Would you describe your poo (also known as faeces, stool) as usually:

hard normal soft runny

39. Is there blood in your poo?

Yes Sometimes No

If you have replied yes or sometimes, you should discuss this problem with the prison nurse 
40. Can you control gas (wind, farts) if you want to?

Yes

No

41. If you have a problem with constipation, or controlling your bowels, did you have these BEFORE you came into prison?

Yes No

(Remember you can ask to speak to the prison nurse if you do have problems)

42. Is there anything else you want to tell us about the problems women might have with going to the toilet, opening their bowels or how they deal with such problems in prison?

Lastly some questions about filling in this questionnaire

43. Did you find the questions easy to understand?

Yes No

44. Were you too embarrassed about the subject of pooing and peeing to answer all the questions?

Yes No

45. Have you written on the form about problems with peeing or pooing that you haven't told anyone else?

Yes No

46. Have you told us about problems that you have already told the prison

nurse or doctors about?

Yes No

Thank you for your help 
$\underline{\text { Table } 1 \text { Demographic characteristics of respondents }}$

\begin{tabular}{|c|c|c|c|}
\hline $\begin{array}{l}\text { Demographic/ } \\
\text { characteristic }\end{array}$ & & $\begin{array}{l}\begin{array}{l}\text { Number } \\
(\mathrm{n}=148)\end{array} \\
\mathrm{n}\left(\%^{+}\right)\end{array}$ & $\begin{array}{l}\text { Missing } \\
\text { data } \\
\mathrm{n}\left(\%^{+}\right)\end{array}$ \\
\hline \multirow{5}{*}{ Age group } & 20 yrs or under & $28(19)$ & \multirow{5}{*}{$1(0.7)$} \\
\hline & 21 to 30 & $50(34)$ & \\
\hline & 31 to 40 & $40(27)$ & \\
\hline & 41 to 50 & $23(16)$ & \\
\hline & 50 or over & $6(4)$ & \\
\hline \multirow[t]{2}{*}{ First Language } & English & $109(74)$ & \multirow[b]{2}{*}{$3(2)$} \\
\hline & Other & $36(24)$ & \\
\hline \multirow{4}{*}{ Age of leaving education } & 12 yrs or less & $15(10)$ & \multirow{4}{*}{$4(3)$} \\
\hline & 16 yrs or less & $73(49)$ & \\
\hline & 17 to $18 \mathrm{yrs}$ & $37(25)$ & \\
\hline & 19 yrs or more & $18(12)$ & \\
\hline \multirow[t]{5}{*}{ Number of children } & None & $49(33)$ & \multirow[t]{5}{*}{$2(1)$} \\
\hline & 1 & $43(29)$ & \\
\hline & 2 & $21(14)$ & \\
\hline & 3 & $15(10)$ & \\
\hline & 4 or more & $18(12)$ & \\
\hline Number pregnant & All prisoners & $14(9)$ & $8(5)$ \\
\hline
\end{tabular}


Table 2 Self Reported Health Problems of Respondents

\begin{tabular}{|l|l|}
\hline Self Reported Health Problem & $\begin{array}{l}\text { Number } \\
\left(\mathrm{n}=91^{1}\right)\end{array}$ \\
\hline Asthma & 13 \\
\hline General malaise unspecified & 11 \\
\hline Depression & 10 \\
\hline Mental health problems unspecified & 9 \\
\hline Musculoskeletal problems & 9 \\
\hline $\begin{array}{l}\text { Blood problems (e.g. anaemia), and } \\
\text { blood born virus (e.g. Hep C) }\end{array}$ & 7 \\
\hline Drug addiction & 7 \\
\hline High blood pressure & 6 \\
\hline Diabetes & 4 \\
\hline Sexual health problems & 2 \\
\hline Skin problems & 4 \\
\hline Psychosis & 2 \\
\hline Hepatitis C & 1 \\
\hline $\begin{array}{l}\text { Other problems reported by only one } \\
\text { individual and not in categorises } \\
\text { above }\end{array}$ & 10 \\
\hline
\end{tabular}

${ }^{1+}$ The same woman could report several health problems 
Table 3 Self reported urinary symptoms

\begin{tabular}{|c|c|c|c|c|}
\hline Symptom & Age group (years) & $\begin{array}{l}\text { Number } \\
\text { respondents } \\
\text { saying yes } \\
\text { n }(\%)\end{array}$ & $\begin{array}{l}\text { Missing } \\
\text { data } \\
\mathrm{n}(\%)\end{array}$ & $\begin{array}{l}\text { Prevalence in } \\
\text { general female } \\
\text { population } \\
\%\end{array}$ \\
\hline \multirow[t]{4}{*}{ Stress incontinence } & $(n=27)$ & $7(26)$ & & \multirow{2}{*}{$20-40^{\dagger}$} \\
\hline & $(\mathrm{n}=84)$ & $22(26)$ & & \\
\hline & 41 or more $(n=29)$ & $15(51)$ & & $30-50^{+}$ \\
\hline & $(\mathrm{n}=140)$ & $44(31)$ & $8(5)$ & \\
\hline \multirow[t]{4}{*}{ Urge incontinence } & $(n=28)$ & $6(21)$ & & \multirow{2}{*}{$20-40^{\dagger}$} \\
\hline & $(\mathrm{n}=84)$ & $17(20)$ & & \\
\hline & 41 or more $(n=29)$ & $13(45)$ & & $30-50^{\dagger}$ \\
\hline & $(\mathrm{n}=143)$ & $36(24)$ & $9(6)$ & \\
\hline \multirow{4}{*}{$\begin{array}{l}\text { Both stress and urge } \\
\text { incontinence (i.e. } \\
\text { mixed incontinence) }\end{array}$} & $(n=28)$ & $16(57)$ & & \multirow{2}{*}{$20-40^{\dagger}$} \\
\hline & $(n=86)$ & $50(58)$ & & \\
\hline & 41 or more $(n=29)$ & $13(45)$ & & $30-50^{\dagger}$ \\
\hline & $(\mathrm{n}=143)$ & $79(55)$ & $5(3)$ & \\
\hline \multirow[t]{4}{*}{ Pain on urination } & $(n=27)$ & $2(7)$ & & \\
\hline & $(n=87)$ & $7(8)$ & & \\
\hline & 41 or more $(n=29)$ & $8(28)$ & & $0.5^{+\dagger}$ \\
\hline & $(\mathrm{n}=143)$ & $17(12)$ & $5(3)$ & \\
\hline Frequency & $(\mathrm{n}=140)$ & $71(48)$ & $8(5)$ & \\
\hline Urgency & $(\mathrm{n}=142)$ & $68(46)$ & $6(4)$ & \\
\hline \multirow{4}{*}{ Nocturnal enuresis } & $(n=28)$ & $1(4)$ & & $0.5^{+}$ \\
\hline & $(n=85)$ & $5(6)$ & & \\
\hline & 41 or more $(n=28)$ & $2(7)$ & & \\
\hline & $(\mathrm{n}=141)$ & $8(6)$ & $7(5)$ & \\
\hline \multirow[t]{4}{*}{ Nocturia } & $(\mathrm{n}=28)$ & $11(39)$ & & \\
\hline & $(n=85)$ & $45(53)$ & & \\
\hline & 41 or more $(n=29)$ & $19(66)$ & & $21^{t+}$ \\
\hline & $(\mathrm{n}=142)$ & $75(53)$ & $6(4)$ & \\
\hline
\end{tabular}

${ }^{\dagger}$ Hunskaar et al, 2005. Median prevalence of any urinary incontinence.

${ }^{\dagger+}$ Perry et al, 2000. 
Table 4 Self reported bowel problems

\begin{tabular}{|c|c|c|c|c|}
\hline Symptom & Age group (years) & $\begin{array}{l}\text { Number } \\
\text { respondents } \\
\text { saying yes } \\
\mathrm{n}(\%)\end{array}$ & $\begin{array}{l}\text { Missing data } \\
\mathrm{n}(\%)\end{array}$ & $\begin{array}{l}\text { Prevalence in } \\
\text { general female } \\
\text { population } \\
\%\end{array}$ \\
\hline \multirow{4}{*}{$\begin{array}{l}\text { Incontinence of } \\
\text { faeces }\end{array}$} & $(n=27)$ & $2(7)$ & & \multirow{4}{*}{$2-5^{\dagger}$} \\
\hline & $(n=84)$ & $4(5)$ & & \\
\hline & 41 or more $(n=27)$ & $5(19)$ & & \\
\hline & $(n=138)$ & $11(8)$ & $10(7)$ & \\
\hline \multirow[t]{4}{*}{ Incontinence of flatus } & $(n=28)$ & $518)$ & & \multirow{4}{*}{$13^{+t}$} \\
\hline & $(n=84)$ & $23(27)$ & & \\
\hline & 41 or more $(n=28)$ & $14(50)$ & & \\
\hline & $(\mathrm{n}=140)$ & $42(30)$ & $8(5)$ & \\
\hline \multirow[t]{4}{*}{ Constipation } & $(n=27)$ & $16(59)$ & & \multirow[t]{4}{*}{$10^{+t t}$} \\
\hline & $(n=86)$ & $55(64)$ & & \\
\hline & 41 or more $(n=28)$ & $17(63)$ & & \\
\hline & $(\mathrm{n}=141)$ & $88(60)$ & $7(5)$ & \\
\hline
\end{tabular}

${ }^{\dagger}$ Kenefick et al, 2004; Perry et al, 2002, ${ }^{+\dagger}$ Sultan et al, 1993 - Prevalence following childbirth,

${ }^{++\dagger}$ Norton, 1996 